\title{
Research on the Cultivating of College English Autonomous Learning Ability
}

\author{
Xiuli $\mathrm{Qu} *$ \\ Teaching and Researching Institute of Foreign Languages \\ Bohai University, Jinzhou, China \\ lename2008@126.com
}

\begin{abstract}
The autonomy in foreign language learning has always been a topic of concern. Its advocates are learner-centered, and the emphas is on the learners' view of being responsible for self-learning has become the core concept of a new round of college English teaching reform. The article starts with selflearning theory, expounds the necessity of independent learning of college English in China, and focuses on the cultivation of college English autonomous learning ability in order to provide some references for college English teaching.
\end{abstract}

Keywords-Cultivating; College English; Autonomous Learning Ability

\section{INTRODUCTION}

In recent years, the rapid development of network technology and the abundance of network resource have made great changes in foreign language teaching models and teaching methods compared to the past. The traditional "cramming" teaching mode and limited classroom teaching information no longer meet the learning requirements of students in the 21st century network environment. The core of the teaching model reform proposed in the "Requirements for College English Courses (Trial)" promulgated by the Ministry of Education in 2004 is: The new teaching model should be supported by modern information technology, especially network technology, so that English teaching can be personalized, Learning, active learning direction is not limited by time and place. Xiao Lijin proposed that the new teaching model should have the following characteristics: (1) Expanding knowledge, cultivating ability, and improving quality; (2) Emphasizing students' dominant position in the teaching process; (3) Strengthening teachers and students Communication and dialogue; (4) Adopting advanced teaching methods and modern teaching methods; (5) Realizing diversification of teaching evaluation models. From this we can see that exploring new teaching models and cultivating students' language comprehensive application abilities and autonomous learning ability have become the core of a new round of college English teaching reform. ${ }^{[1]}$

\section{The Concept Definition of Autonomous LeARning}

Autonomous learning, as a kind of personalized learning, embodies the concept of constructivist theory that learners create personal meaning on the basis of existing knowledge. The emphasis on the learner's subjective status in the learning process is an important idea of humanistic psychology. In his book Autonomy and Foreign Language Learning, Holker took the lead in introducing the concept of "self-directed learning" into language learning, and defined the learner's autonomy as the ability to be responsible for his own learning. It is mainly reflected in five aspects: determine learning objectives; determine learning content and progress; choose learning methods and techniques; monitor the learning process; little thought that autonomous learning is the ability of learners to criticize, make decisions, and act independently. Based on past research, Damm pointed out that autonomous learning depends not only on individuals, but also on groups. Learners can only acquire the ability to learn autonomously by working with others. Therefore, interaction, negotiation, cooperation is very important for the development of learners' autonomous learning ability. Dickinson believes that self-directed learning is not only a learning attitude, but also an independent learning ability. Benson believes that the autonomy of language learning includes three aspects: Autonomous learning is an independent learning behavior and skills; Autonomous learning is an intrinsic psychological kinetic energy that guides oneself learning; Autonomous learning is a kind of self-learning content control.

\section{ThE TheORETICAL BASIS FOR INDEPENDENT LEARNING}

Self-directed learning is based on the principles of constructivism and humanism. It is a learner's ability to take responsibility for his or her own learning, including determining learning objectives, determining learning content and progress, selecting learning methods and skills, monitoring the learning process, and assessing learning effectiveness. Dickinson believes that autonomous learning is both a learning attitude and an independent learning ability. Learners can identify, plan and change goals to adapt to their learning needs and interests, and can use learning strategies to monitor their own learning. Benson proposed that the autonomy of language learning is mainly reflected in learners' independent learning behaviors and skills, knowing their own inner psychological dynamics of learning, and controlling their own learning content in three aspects. After combining the characteristics of Chinese college English teaching, Xu Jinfen et al. proposed the student's autonomous English learning ability under the English teaching environment in China. It should cover five aspects: understanding the teaching objectives and requirements of teachers; establishing learning objectives and formulating learning plans; effective use learning strategies; Monitoring the use of learning strategies; Monitoring and evaluating the learning process. ${ }^{[2]}$ 
The concept of autonomous learning was first proposed by the Western scholar Holker in 1981. He defined autonomous learning as the learner's own responsibility for learning during the process. He believes that from a learner's point of view, autonomous learning ability means gaining the goals, content, materials, and methods of determining learning, determining the time, place and progress of learning, and the ability to evaluate their own learning. Benson believes that the autonomy of language learning includes the learner's learning depends entirely on himself, learners' responsibility for their own learning, and learners' right to determine their own learning goals. Chinese scholar Wang Xiqin's research at home and abroad defines self-study as: setting learning goals according to his own situation, formulating learning plans, selecting learning methods, monitoring the learning process, implementing the monitoring learning plan, using and developing skills, and selfexamination and assessment. ${ }^{[3]}$

Although scholars at home and abroad have different definitions of autonomous learning, their core content is basically the same, that is, learners are responsible for their own learning during the learning process. This is a kind of teaching model that takes students as the main body and teacher-oriented, which not only cultivates students' language comprehensive utilization ability, but also focuses on developing students' autonomous learning ability. Autonomous learning is an active, and conscious behavior of learners. It requires learners to consciously adjust their own learning strategies and efforts according to their learning abilities and learning tasks. Chinese scholar Xu Jinfen proposed the main contents that should be covered by the English autonomy learning ability of Chinese college students: (1) Understand the teaching objectives and requirements of teachers; (2) Establish learning objectives and formulate learning plans; (3) Effective use of learning strategies (4) Monitor the use of learning strategies; (5) Monitor and evaluate the English learning process.

\section{The Necessity of Autonomous Learning in College ENGLISH}

Foreign language learning is an autonomous acquisition process. Acquirers often need to consciously adjust their own learning methods, learning strategies and other cognitive means to complete the learning task. Chinese students learn foreign languages and their mother tongues are of different languages. Their cultural traditions, language features (including phonetics, grammar, and text systems) differ greatly from their mother tongue. Foreign language learning is far more difficult than that of mother-tongue acquisition. Learners who have very good strong self-learning awareness can effectively learn foreign languages. The famous linguist Cohen pointedly stated: The success of language learning depends on the learner himself and on the learner's own factors and his various abilities to make full use of the learning opportunities. Teachers' teaching in the classroom can only provide part of language input. A large amount of learning and practice outside the classroom is an important guarantee for the success of foreign language learning. This characteristic of foreign language learning requires students to have strong independent learning ability. Self-study is the key to foreign language acquisition. The ability of the learner to successfully learn a foreign language depends on his autonomous learning ability. ${ }^{[4]}$

As an important component of China's higher education, college foreign language teaching plays a decisive role in the development of the entire education. However, a series of problems in current college English teaching make college English teaching reform inevitable. First of all, an increasing number of college English classes led by the expansion of enrollment require the adoption of new teaching models. Secondly, social, economic, and political development put forward higher requirements for college students' listening and speaking abilities. In addition to the counseling of teachers in the classroom, students are required to exercise through extracurricular learning outside of class. Finally, the development of the times, social progress, and the renewal of knowledge require the improvement of the overall quality of modern college students and the development of life-long learning capabilities. Not only do college students need to acquire specific knowledge, but they also need to learn to acquire knowledge and learn independently. ${ }^{[5]}$

\section{Experimental Research on Teaching Strategies of Cultivating Students' Autonomous Learning Ability}

This research is quasi-experimental research. Two classes with middle-intermediate students are the experimental class and the control class. Two classes are taught by the same teacher. The same curriculum is used. The same textbook, New Horizon College English, relies on the new horizon network teaching. The training strategies for students of experimental class to apply systematic self-learning abilities include three aspects: motivating and cultivating learning motivation, training of learning strategies, and development of selfmonitoring skills. The three teaching strategies permeate the students' self-directed learning. The effect of experimental factors on the students' English performance and self-learning ability was tested through experimental processing. The online self-directed learning of students in the control class only provides guidance on the specific issues raised by the students. The focus of class teaching is on the content of the unit rather than on skills.

Learning Motivation Training. Prior to student self-learning, online English proficiency assessment, starting point testing, and learning process control are used to help students set reasonable learning goals. In the process of self-directed learning, teachers provide a guideline for students to identify unit learning goals and specific learning tasks, teacher evaluation methods, etc.; to create a collaborative learning atmosphere through online communication, topic discussion, and cooperative learning, so that students in specific sensible situations, learning tasks are completed in peer support and care. After the classroom instruction, the students responded to feedbacks and evaluations of teachers' face feedback, online tests, and learning records. They saw the progress of learning, made clear the differences between their own learning process and results, and teaching requirements, increased their confidence in learning, and triggered self-directed learning.

Learning Strategy Training. Prior to independent study, teachers formulate long-term and short-term teaching plans and evaluation criteria, and help students to set up reasonable and 
feasible learning plans to enhance students' planning awareness; provide specific recognition online for different students' learning problems. Knowledge strategies, for students' reference, encourage students to enter different learning modules based on learning content, English level, and topics of interest to practice; allow students to identify different advantages of paper materials, computer networks, multimedia and other resources, based on individuals' actual situation and learning needs, choose the right media resources. In the process of self-directed learning, teachers conduct individual instruction and classroom learning strategy training to enhance students' effectiveness in the use of learning strategies; provide ongoing teaching concerns and help students adjust learning strategies to better implement plans; provide students with learning content website, and opened up a variety of helpseeking channels, such as online search, teacher answering questions, classmates discussion, etc., to enable students to solve problems in a timely manner and gain the initiative to learn.

Self-Monitoring Ability Training. In the self-learning process of students, teachers' external feedback and evaluation are enhanced. Individuals and class test records and learning records are viewed in a timely manner to understand the students' learning situation and difficult issues. In order to provide timely counseling and help, the external monitoring is gradually reduced to guide students. Self-questioning enhances the subjective awareness of students' self-monitoring. In particular, after self-study, students are organized to carry out study summaries; through a portfolio evaluation method, students are actively guided to reflect on the learning content and the learning process. Students share the learning results with their classmates and teachers and at the same time their awareness of participation has been enhanced and their critical thinking and other related skills has been developed during this process. At the initial stage of the experimental study, a Z-test was conducted on the college entrance examination results of the two classes of students. It was found that there was a large difference in student enrollment levels. The control class was much higher than the experimental class and the standard deviation gap was quite large. In order to ensure the effective operation of the experiment, the number of comparisons in the results of the experimental class was determined as 30 students after the value was excluded.

TABLE I. DIFFERENCES BETWEEN THE TWO CLASSES BEFORE THE TEST

\begin{tabular}{|c|c|c|c|c|}
\hline Pretest & $\begin{array}{c}\text { Number } \\
\text { of people }\end{array}$ & $\begin{array}{c}\text { The average } \\
\text { score }\end{array}$ & $\begin{array}{c}\text { Standard } \\
\text { deviation }\end{array}$ & $\begin{array}{c}\text { Significant } \\
\text { level }\end{array}$ \\
\hline $\begin{array}{c}\text { Experimental } \\
\text { class }\end{array}$ & 30 & 123.48 & 6.29 & \multirow{2}{*}{$|\mathrm{Z}|=0.51<1}$. \\
\cline { 1 - 2 } Control class & 42 & 124.47 & 5.03 & 96 \\
\hline
\end{tabular}

One year later, comparing the students' final exam results (out of 100 points), it was found that the difference in English scores between the two classes of students was very significant, and that the experimental class was higher than the control class. At the same time, the standard deviation of the performance of experimental classes and control classes is increasing, which means that after one year of study, the problem of polarization of students' English proficiency increases, and the polarization of control classes is even more serious.
TABLE II. COMPARISON OF DIFFERENCES AFTER TWO SHIFTS

\begin{tabular}{|c|c|c|c|c|}
\hline Posttest & $\begin{array}{c}\text { Number } \\
\text { of people }\end{array}$ & $\begin{array}{c}\text { The average } \\
\text { score }\end{array}$ & $\begin{array}{c}\text { Standard } \\
\text { deviation }\end{array}$ & $\begin{array}{c}\text { Significant } \\
\text { level }\end{array}$ \\
\hline $\begin{array}{c}\text { Experimental } \\
\text { class }\end{array}$ & 30 & 66.93 & 7.57 & \multirow{2}{|Z}{$|\mathrm{Z}|=3.60>$} \\
2.58
\end{tabular}

The application of computer network technology provides students with the necessary material basis for English learning and autonomous development. However, autonomy is the unification of rights and responsibilities. Students with strong self-learning ability have greater room for development under the new teaching model. However, students with poor learning foundations, lack of interest in learning, and have weak willpowers, who have long been dependent on teachers in the middle school stage and have not yet formed a systematic English cognitive strategy structure. It cannot provide the necessary cognitive foundation for continuing learning. It is overwhelmed by the learning environment for selfdevelopment, and it is unable to make effective use of learning resources, thus creating learning difficulties. The polarization of the control class is more serious than that of the experimental class, which shows that the teaching strategies can effectively reduce students' polarization. However, solving this problem thoroughly requires the teacher's long-term correct guidance to help students establish a correct learning concept, enrich cognitive strategies, and enhance selfmonitoring ability, gradually improve self-learning ability.

This shows that the teaching strategies for developing autonomous learning ability are generally conducive to the development of students' autonomous learning ability. They are no longer satisfied to study according to the requirements of teachers, because they usually have clear learning needs, thus requiring teachers to provide teaching assistance according to their own learning status. They often give teachers advice through the learning summary, and hope to get the teacher's support and help, which consequently increased students' awareness of learning. They actively participate in learning activities, learn to think independently, dare to challenge, dare to innovate, and require the initiative to obtain teaching; Students recognize the characteristics of various resources, can effectively use various network resources to carry out learning activities; Have a certain degree of regulation and control capabilities. With a certain ability to reflect and evaluate, they can find out their own shortcomings in time, and actively think of ways to improve.

\section{The Development of College English Autonomous LEARNING ABILITY}

Training and development of "self-learning by learners" is conducive to quality education, but it is necessary to eliminate the interference of exam-oriented education and get out of the misunderstanding of exam-oriented education. Just as students should learn to be responsible for their own learning, teaching management departments and teachers should also think about how to create and develop the environment and atmosphere for student self-learning. The education management department should begin to construct a multimedia network teaching environment; give full play to the advantages of multimedia teaching; establish a college English autonomous learning 
environment based on computers and networks; promote individualized autonomous learning of students; improve the pertinence of teaching, and cultivate comprehensive English skills. However, self-directed learning does not mean that learners are completely independent from teachers and peers and carry out learning activities in isolation. They must rely on a relaxed, harmonious, and mutually beneficial interpersonal atmosphere to develop. Therefore, on the one hand, teachers should always provide guidance, feedback, encouragement, and assistance to students in the identity of helpers, facilitators, consultants, negotiators, and consultants both inside and outside the classroom in order to establish a good teacherstudent relationship. Good teacher-student relationship is an important part of the autonomous learning atmosphere. Teachers can only change the image of former authoritarians and monopolists, communicate with students on an equal basis, and conduct consultations and discussions with students. They can form a kind of interpersonal relationship in which teachers and students can work together closely to create an atmosphere conducive to student self-study. On the other hand, the role of peers in learner' autonomous learning cannot be ignored. Due to the special nature of foreign language acquisition, the development of foreign language vocabulary, grammar, pronunciation, and the skills of listening, speaking, reading, writing, and translating are inseparable from teachers' guidance, but they also lack the help of their peers.

In order to realize the student's ability to study independently and to exert the subjective role of the students in the process of knowledge construction, teachers should change their traditional roles and continuously improve their own business level. In the process of self-directed learning, teachers are no longer merely knowledge provider in the traditional sense, but also play other important roles such as mentor, facilitator, and coordinator. Therefore, in order to ensure students' self-directed learning, teachers should continue to develop their own independent development abilities in the process of teaching and career development. First, English teachers should continue to consolidate their basic language skills and maintain a high level of English because language is the basic guarantee for those who are determined to be English teachers. Second, college English teachers must reinforce the study of English teaching theory, understand the latest trends in teaching and research through various channels and understand and accept advanced concepts of education, and use leadingedge theories to guide teaching practice. Third, English teachers ought to study relevant knowledge of educational psychology, understand the emotional psychology of students, improve the scientific nature of self-directed learning guidance, strengthen the awareness of teaching research, and fully understand the significance and role of teaching research in improving one's own quality and teaching level, and conscientiously rethinking the teaching practice, analyzing and exploring the problems that arise, and summarizing the accumulated experience to achieve self-development and improvement of teaching standards. Fourth, university English teachers should also learn and master the latest modern educational technologies, including multimedia and network technologies, and strive to be proficient in the use of computers and networks to obtain information, store information, filter information, and integrate it into teaching resources and apply them. Do understand the use of various teaching software, and can correctly guide students to use software and e-learning. Fifth, College English teachers should establish the concept of lifelong learning and become lifelong learners. Through continuous learning, they can expand their knowledge, improve their own cultural qualities, and actively participate in various trainings to improve their ability structure.

Self-learning awareness is a prerequisite for learners to conduct autonomous learning. Teachers should first cultivate the learners' awareness of self-directed learning and help establish a correct view of English learning. That is, foreign languages are learned, not taught, and foreign languages are mainly dependent on students themselves. On the basis of improving learners' awareness of self-regulated learning, teachers should also strengthen the development of their learning strategies. Foreign language teachers must consciously develop students' abilities to use learning strategies to guide students to develop unique learning methods and strategies that are suitable for them and adjust them continuously. The study of foreign language acquisition abroad shows that there are large individual differences in the learning methods of foreign language learners due to such factors as personality, experience, environment, and cultural background. All in all, teachers should give students guidance in learning methods so that students can develop unique learning methods that suit themselves and learn effectively.

\section{SUMMARY}

The development of the self-learning awareness of foreign language learners has important guiding and practical significance for the reform of foreign language teaching in China today. In addition, the realization of autonomous learning is a systematic project that not only requires the transformation of the guiding ideology of foreign language teaching, but also requires thorough reforms in the teaching environment, teaching content, teaching methods, and teaching methods.

\section{REFERENCES}

[1] L. Xiao, On the Macro Mode of Chinese English Teaching [J]. Foreign Language Teaching, 2005, (5):35-41. (In Chinese)

[2] J. Ouyang, Q. Hu, Exploration of Comprehensive Training Model of College English Autonomous Learning Ability [J]. Yun Meng Xue Kan, 2008, (6): 141-144. (In Chinese)

[3] J. Xu, X. Zhan, Review of "Student Autonomy" at home and abroad [J]. Foreign Languages, 2004, (4): 2-9. (In Chinese)

[4] Z. Du, T. Yun, On College English Autonomous Learning under Network Environment [J]. China Electrification Education, 2012, (6): 112-114. (In Chinese)

[5] Z. Wu, Controlling Signs of Suppressing Course Autonomy-Discourse Rights of Teachers' Development[J]. Foreign Languages and Their Teaching, 2004, (183): 30-34. (In Chinese) 